\title{
Regulating disasters? The role of international law in disaster prevention and management
}

Article

Accepted Version

Aronsson-Storrier, M. and da Costa, K. (2017) Regulating disasters? The role of international law in disaster prevention and management. Disaster Prevention and Management, 26 (5). pp. 502-513. ISSN 0965-3562 doi:

https://doi.org/10.1108/DPM-09-2017-0218 Available at https://centaur.reading.ac.uk/72744/

It is advisable to refer to the publisher's version if you intend to cite from the work. See Guidance on citing.

To link to this article DOI: http://dx.doi.org/10.1108/DPM-09-2017-0218

Publisher: Emerald Publishing

All outputs in CentAUR are protected by Intellectual Property Rights law, including copyright law. Copyright and IPR is retained by the creators or other copyright holders. Terms and conditions for use of this material are defined in the End User Agreement.

www.reading.ac.uk/centaur 
Central Archive at the University of Reading

Reading's research outputs online 


\title{
Regulating Disasters? The Role of International Law in Disaster Prevention and Management
}

\begin{abstract}
Purpose - This article explores the role of international law in disaster prevention and management, with a particular focus on the emerging field of international disaster law, and its relationship with international human rights law. It further introduces the four articles of the special column of this journal issue, dedicated to disasters and international law.

Design/methodology/approach - The analysis is based upon primary sources of legislation and policy, as well as academic literature on disasters and international law.

Findings - Although the field of international disaster law is at its infancy, we argue that this emergent area does have the potential to gain widespread recognition as a distinct field of law, and that this could be of benefit for the wider disaster management community.

Originality/value - The article introduces key legal features and themes relating to international law and disasters, highlighting their relevance for disaster management. The added value is to widen the discussion on aspects of disasters regulated by international law, thus facilitating the future exchange with other academic subjects and operational fields.
\end{abstract}

Keywords - disasters; international law; disaster management; treaties; human rights; international disaster law; international human rights law.

Paper type - Research paper

\section{International Disaster Law}

\subsection{Introduction}

The past few years have seen a remarkable shift in the acknowledgment of the role of law in the management of disasters. Importantly, the developing field of international disaster law (IDL) has moved from a strong focus on disaster response and relief, towards a more holistic view of the role of law in disaster prevention and management. The field, as is now developing, builds upon and around other areas of (international) law, such as international human rights law (IHRL) (IASC, 2011; Lauta, 2016), international environmental law (Stephens, 2016; Peel and Fisher, 2016), climate change law (Lyster, 2016), and international water law (Phan and Winkler, 2016).

Rather than a coherent corpus of law, IDL, in its current form, can be considered an "overarching umbrella", under which various areas of law are integrated into the context of disaster management (Breau and Samuel, 2016). One of the core challenges for scholars currently working in this multifaceted area of international law is how to account for its fragmented legal foundations, in order to achieve a more comprehensive account of IDL. Although this work is in its infancy, important progress has already been made through academic initiatives (see, especially, Breau and Samuel, 2016; Caron et al., 2014; Lauta, 2015; de Guttry et al., 2012) as well as through the International Federation of the Red Cross and Red Crescent Societies (IFRC) International Disaster Law Programme. ${ }^{\text {i }}$

Law has for long sought to regulate human-made hazards. Regulations and agreements have arisen within specific fields - such as the the 1986 Convention on Assistance in the Case of Nuclear Accident and Radiological Emergency, the 1990 International Convention on Oil Pollution Preparedness, Response and Cooperation, and the 1993 Convention concerning the Prevention of Major Industrial Accidents - in order to prevent and provide accountability for disasters. The focus on human-made hazards is also visible in relation to law regulating humanitarian aid, which has mainly been developed in 
relation to the context of armed conflicts (see, especially, the four Geneva Conventions of $1949^{\mathrm{ii}}$ ), with much less said about relief in the disaster context (the International Relief Union, which was founded in 1927, only took action in two disasters, before it was officially dissolved in 1967. See Macalister-Smith, 1981). In relation to natural hazards, questions around accountability and responsibility become all the more difficult to address, and the law has taken significantly longer to reach this space.

The current picture of IDL is a scattered one, where important legal instruments regulating key aspects of disaster relief operations (such as the 1998 Tampere Convention on the Provision of Telecommunication Resources for Disaster Mitigation and Relief Operations) exist, but where these are not necessarily linked with further related instruments so as to create a comprehensive body of law. This is unsurprising considering that IDL only recently started gaining significant attention. Notably, International Disaster Response Law (IDRL), which is widely considered to be the most established part of IDL, was still considerably underdeveloped at the turn of the millennium (IFRC, 2000; for an earlier analysis of the state of the art, see Macalister-Smith, 1985). Still today, the patchwork of applicable laws and agreements makes it challenging to identify the international legal coverage in a given disaster.

Another non-negligible dimension of the regulation of disasters is the role played by national legislation. This is indeed key in any disaster prevention effort or relief operation, especially for first responders. Although national legislation is not the focus of the analysis in this column, noticeable initiatives have influenced significant developments of national regulation of disaster-related issues. The Checklist on Law and DRR jointly developed by the IFRC and United Nations Development Programme (UNDP) is one key example. The Checklist aims to contribute to reducing disaster risks through supporting national authorities in improving relevant laws and regulations, together with strengthening their implementation, so as to make sure they effectively support DRR (IFRC and UNDP, 2015).

In addition to the core international and national legal frameworks, there are a number of regional and bilateral agreements regulating various aspects of disaster response and DRR. Examples include the 2005 ASEAN Agreement on Disaster Management and Emergency Response; the 1991 OAS Inter-American Convention to Facilitate Disaster Assistance; and articles 196, 214 and 222 of the Treaty on the Functioning of the European Union, to name a few.

We would argue that law can be a powerful tool through which to drive change. However, in relation to disasters - as with other areas of (international) law - often the people most at risk are also those without a strong voice to affect law and policy. It is important, therefore, that the development of IDL takes at its very heart the people affected by disasters. The importance of putting the individual at the heart of any regulation of disaster management is one of the reasons why the contributions to this special column cover human rights aspects relevant in disasters, as discussed later on.

\subsection{ILC Draft Articles on the Protection of Persons in the Event of Disasters}

The growing recognition of the role of international law in disaster management can be seen in the work of the International Law Commission (ILC), a body under the UN General Assembly which plays an important role in the progressive development and codification of international law (in accordance with the Charter of the United Nations, art. 13(1)(a)). In 2007, the ILC initiated a project exploring the legal aspects of the protection 
of persons in the event of disasters (ILC, 2007), resulting in the drafting and adoption by the same body of the 2016 Draft Articles on the Protection of Persons in the Event of Disasters (Draft Articles) (ILC, 2016). Although the Draft Articles are not binding upon States, they carry particular weight as States and other actors, including the UN Office for Disaster Risk Reduction (UNISDR) and the IFRC, have been consulted throughout the process.

It should also be mentioned here that the Draft Articles may in the future be adopted as a treaty. Indeed this has been the recommendation by the ILC to the General Assembly, to elaborate a convention on the subject, based on the draft articles (ILC, 2016, paras. 43-46). However, a number of States rejected this idea at this point of time (see, e.g., UNGA Sixth Committee, 2016), and it is by no means certain to occur. To date, the UN General Assembly has taken note of the Draft Articles, and invited Governments to submit comments on the ILC recommendation. The General Assembly has further decided to include an item entitled "Protection of persons in the event of disasters" in the provisional agenda of its seventy-third session, 2018 (UNGA, 2016).

The purpose of the ILC Draft Articles is "to facilitate the adequate and effective response to disasters, and reduction of the risk of disasters, so as to meet the essential needs of the persons concerned, with full respect for their rights" (Draft Article 2). One of the key issues has been to find a balance between this intent to protect people, and the principle of state sovereignty, clearly stated in Draft Article 13, according to which the "provision of external assistance requires the consent of the affected State", while such consent "shall not be withheld arbitrarily".

The Draft Articles define "disaster" as "a calamitous event or series of events resulting in widespread loss of life, great human suffering and distress, mass displacement, or large-scale material or environmental damage, thereby seriously disrupting the functioning of society" (Draft Article 3(a)). This is currently the most authoritative international legal definition of "disaster", but still raises a number of significant questions. For example, what is a calamitous event? How are criteria such as "great human suffering" to be measured? And what constitutes a serious disruption of society? All these questions call for further research and analysis as we move forward. A more comprehensive overview of different legal definitions of disaster can be found in Karen da Costa's contribution to this column. Another feature relating to the definition of disaster as adopted in the ILC Draft Articles is that it does not include armed conflict (see, especially, Valencia-Ospina, 2008, 153; Draft Article 18). The relationship between IDL and international humanitarian law (IHL) warrants more research, in particular in relation to complex emergencies, and has already received some scholarly attention (e.g. Venturini, 2012; Rodenhäuser and Giacca, 2016).

Although the main focus of the Draft Articles is disaster response and relief efforts, they also apply to disaster risk reduction (DRR) measures. Draft Article 9 requires states to "reduce the risk of disasters by taking appropriate measures, including through legislation and regulations, to prevent, mitigate, and prepare for disasters." While not explicitly referring to the UN Sendai Framework for Disaster Risk Reduction (SFDRR) discussed below, the commentary to refers both to the SFDRR and the work of the Open-ended Intergovernmental Expert Working Group on Indicators and Terminology Relating to Disaster Risk Reduction (ILC, 2016, p. 41 ff), thus establishing strong links between the ILC Draft Articles and DRR law and policy. 
The Draft Articles constitute a framework for the field of disaster law, and notably establish, with considerable weight, the obligations of States in relation to the protection of persons in disasters. As such, they are of immense value. Still, they leave many questions unanswered as to their interpretation, aspects of which are discussed in the contributions to this column. Importantly, the Draft Articles make numerous references to the application of human rights in disasters, but there are still significant uncertainties as to how to interpret existing human rights obligations in the disaster context.

\subsection{UN Sendai Framework for Disaster Risk Reduction 2015-2030 (SFDRR)}

Another recent key development that fosters IDL is the adoption by States of the SFDRR, during the Third UN World Conference on Disaster Risk Reduction, held in Japan. Designed to succeed the Hyogo Framework for Action 2005-2015, the document is a result of various stakeholders' consultations and inter-governmental negotiations.

The SFDRR is organized along seven targets and four priorities for action, aiming at substantially preventing new and reducing the risk of disasters by 2030. It recognizes that States have the primary responsibility to reduce disaster risk (Guiding Principle 19(a)), but that responsibility should be shared with other stakeholders, including local governments and the private sector (Guiding Principle 19(b)). It equally recognizes that DRR requires an all-of-society engagement and partnership (Guiding Principle 19(d)). This stresses the urgency of exploring the roles and responsibilities of various actors involved in disaster prevention and management, notably non-state actors, a matter discussed by Marlies Hesselman and Lottie Lane in their contribution to this special column.

Although technically speaking the SFDRR is considered non-binding "soft law", due to it being adopted as a UN General Assembly resolution, which generally does not give rise to legally binding obligations to States, the adoption of this document clearly evidences states' shared vision in terms of future steps towards real progress on DRR. In this sense, this is an important development for the emerging field of IDL, for it provides a framework informing action both nationally and internationally in this area.

\section{Disasters and International Human Rights Law}

The reader will notice that all four contributions in the current special column relate to international human rights law. Although we will introduce each article in due course, the general explanation for this is simple: human rights are indeed an area of international law that has steadily developed in the last few decades, and while the relationship between human rights and disasters has lately received significant attention, from both legal practitioners and academics alike (Kälin and Dale, 2008; Carmalt and Dale, 2012; Sommario, 2012; Cubie and Hesselman, 2015; Da Costa and Pospieszna, 2015), it is clear that the issue warrants deeper and more extensive analysis. Considering the move from a needs-based to a human rights-based approach to disaster management, some have suggested that the protection from human rights violations in disasters is as important as the provision of relief. Bizarri argues that:

Human rights abuses further undermine people's resilience, as well as their ability to contribute more effectively to, and benefit fully from the opportunities offered by recovery and transition. Yet, in the rush to provide for basic needs, less attention is often devoted to the need for human rights protection, with negative implications for the effectiveness and long-term impacts of humanitarian response. (Bizzarri, 2012; see 
also HRC, 2015)

This statement may come as a surprise for some practitioners in the disaster field, who might perceive human rights as potentially politicized and counter-productive in their dayto-day practice. However, in order to avoid further disasters from occurring, and also during the response to and reconstruction after disasters, human rights should be taken into account, so as to ensure a lasting legacy, and not simply the reinstatement of a discriminatory status quo. IHRL grants human rights to each and every individual. Thus, if applied correctly, it can be a powerful tool through which to address discrimination, marginalisation and vulnerability.

Categories of individuals that are likely to be found in a position of vulnerability in disasters include women; children; older persons; persons with disabilities; and minorities and indigenous groups (Bizzarri, 2012; Crock, 2016; HRC, 2015). Further individuals sometimes considered especially vulnerable in disasters are those with a disadvantaged socio-economic status; those in remote geographic locations; and those with a somewhat precarious legal status, such as refugees, internally displaced persons, and migrants. The vulnerability of distinct categories of individuals can be further exacerbated when different features often linked to discrimination intersect. This takes place for example when gender discrimination intersects with discrimination based on ethnicity, race, age, disability, etc. (Bizzarri, 2012; Crock, 2016).

Why are these categories of people considered to be in a likely position of vulnerability, which is heightened in disasters? Because of pre-existing conditions that make them more vulnerable, which are present long before disasters occur. These conditions relate to the adverse way in which a given society treats persons, especially due to their gender, age, disability or ethnicity. Such unfavourable treatment and the higher vulnerability that it leads to become apparent in disasters, when these individuals need specific protection (Crock, 2016; HRC, 2015).

To illustrate this, consider the example of how gender inequalities limit women's mobility. In many countries, both girls and women are not taught to swim. In a disaster, this lack of preparation may make them more vulnerable than boys and men, especially when it consists of floods and inundations. This has dire consequences for women and girls' human right to life. Globally, for every 1 man who dies in a flood, 3-4 women lose their lives (Bizzarri, 2012).

Such heightened vulnerability has a negative impact on the enjoyment of human rights by those in each identified category. This negative impact encompasses all phases in the disaster cycle (namely preparedness, response and recovery).

There are many further examples covering both disaster response and recovery. Shortly after a disaster, and sometimes, for much longer, people may be injured, separated from their families, without a shelter, and with limited or no access to basic goods and services. Furthermore, the chaos and lawlessness often associated with disasters leave people at risk of various human rights violations and abuses. This may comprise lack of safety, both personal safety, linked to various forms of exploitation and abuse especially of children and women, such as sexual exploitation and forced prostitution; trafficking; and violence by both family members or by cohabitees in shelters, sometimes even by humanitarian workers (Bizzarri, 2012; Crock, 2016; IFRC, 2006, Chapter 6). Furthermore, 
discriminatory patterns in a given society may already deny certain categories of people, for example women, access to and control of productive assets, such as having a title to land. Once a disaster strikes, such patterns may lead to the unequal access to assistance, reparation and restitution.

In terms of what can be done to safeguard human rights in disasters, we would like to highlight two aspects of key importance: (1) international human rights legal standards, which are also relevant in disasters; and (2) mechanisms set up to monitor their observance. Both aspects are addressed in turn below.

\subsection{International human rights legal standards of relevance for disaster prevention and management}

Both the International Covenant on Civil and Political Rights (ICCPR) (which covers, among others, the right to life, and freedom of movement) and the International Covenant on Economic, Social and Cultural Rights (ICESCR) (covering among others the right to health, housing, food, and education) are of great significance for disaster prevention and management. These treaties are not tailored made to any particular category of persons identified above as potentially vulnerable in disasters. Nevertheless, as a general rule, all persons will benefit from their coverage (though there are some rights covering citizens only, such as the right to vote and to be elected, article 25 ICCPR).

Further to the general human rights treaties, others focus on a particular category of individuals, which are also considered more likely to be in a position of vulnerability in disasters. Examples include the Convention on the Elimination of All Forms of Discrimination Against Women (CEDAW), and the Convention on the Rights of the Child (CRC). Relevant provisions include article $15 \mathrm{CEDAW}$, which covers the equality of women and men before the law; and articles 13 and 14 CEDAW, covering access of women to general and agricultural credit and loans. In relation to the $\mathrm{CRC}$, an important provision is article 7, covering birth registration, something that may play a role in disaster management initiatives, such as programmes on the allocation of temporary shelter and also on family reunification.

A more direct link to disaster management can be found in the Convention on the Rights of Persons with Disabilities (CRPD). Article 11 requires State Parties to:

(...) take, in accordance with their obligations under international law, including international humanitarian law and international human rights law, all necessary measures to ensure the protection and safety of persons with disabilities in situations of risk, including situations of armed conflict, humanitarian emergencies "and the occurrence of natural disasters". (emphasis added)

Further developments can be found at the regional level. An example of regional human rights treaty covering mostly civil and political rights in a general fashion (that is, in relation to all individuals), is the 1950 European Convention on Human Rights (ECHR). Other regional treaties, such as the 2009 AU Kampala Convention on Internally Displaced Persons (IDPs) (African Union Convention for the Protection and Assistance of Internally Displaced Persons in Africa), contains several references to ("natural" and human-made) disasters, together with references on the need to protect IDPs in this context. Also the 
1990 (Organisation of African Unity) African Charter on the Rights and Welfare of the Child has a clear reference to disasters, in its article 23. Although the article as such was designed primarily to cover refugee children, the protection it affords is extended to IDP children through its fourth paragraph, which states that:

The provisions of this Article apply mutatis mutandis to internally displaced children whether "through natural disaster", internal armed conflicts, civil strife, breakdown of economic and social order or howsoever caused. (emphasis added)

This brief outline of key supranational human rights legal standards is intended to highlight some of the existing normative instruments, the knowledge of which may benefit the disaster community. The reasons for their relevance are manyfold. First of all, because some treaties cover human rights in a general fashion, all disaster victims would be covered by them. This can be crucial, as not all potentially vulnerable groups are the subject of a special treaty designed to meet their particular needs. Secondly, there are treaties dedicated to particular categories of individuals likely to be in an increased position of vulnerability in disasters. Thirdly, some of these treaties contain provisions that directly refer to disasters, which are worth the disaster community knowing. And finally, despite the fact that international law, including IHRL, is far from a panacea in terms of effectively addressing the many challenges concerning human rights and disasters, it does bind States. Thus, States that voluntarily committed to these standards will undoubtedly have related legal obligations to meet these commitments. All in all, international standards as those highlighted above may support and strengthen advocacy efforts and the conceptualization and delivery of disaster-related programs by the disaster community.

\subsection{Mechanisms set up to monitor the observance of international human rights legal standards}

Beyond the existence of normative standards relevant to disasters, it is also worth introducing mechanisms that have been setup to monitor States' compliance with their international legal obligations. Although this section has no ambition to exhaustively cover the topic, it intends to signalise some relevant developments on this front.

United Nations treaty bodies (UNTB) have addressed disaster-related features and their effects on human rights, through pronouncements and general comments, on numerous occasions. One example is the assessment by the Committee in charge of monitoring States' compliance with the CEDAW, of the situation of women in Chile, namely the impact of the 2010 earthquake and tsunami on their socio-economic situation, notably the situation of women in rural areas. For the Committee, national reconstruction efforts did not take women's specific needs into account, and it recommended Chile to integrate a gender perspective in all state programs and strategies designed as response to "natural" disasters (CEDAW Committee, 2012). Although the language used by the Committee (also found in some treaty provisions covered in the previous section) is to be regretted (using "natural disasters" instead of natural hazards leading to disasters), the indication that States have a legal obligation arising from the convention to take into account women's needs in disaster-related policies is to be welcomed. Though not legally 
binding, the UNTBs' pronouncements are indeed taken seriously by many states that go through their monitoring system, which have agreed to be bound by the legal standards these bodies were designed to monitor.

In addition to the UNTBs, the European Court of Human Rights (ECtHR) has increasingly addressed human rights issues arising in disasters, evidenced through both landmark judgments in Öneryildiz v. Turkey (2004) and Budayeva and others v. Russia (2008). In the first case, the Court concluded that authorities had acted with gross negligence, by failing to take precautionary measures after a methane explosion in a rubbish tip in a slum quarter in Istanbul had caused 39 deaths and loss of property (slum dwellings of impoverished families living nearby). Turkey was found in violation, among others, of the right to life and the right to property.

The second case covered a series of mudslides in a locality known to be prone to such hazards, which resulted in the death of 8 people. Stating that the lack of timely preventive action by authorities was to blame for the loss of life, the Court found Russia in violation of article 2 ECHR (right to life). For the Court, states are expected in similar situations to inform the public about any life-threatening emergency; to put early warning systems in place, and to install proper defense infrastructure. In this case, the court paid particular attention to the origin of the threat (linked to a natural hazard) and the extent to which it was susceptible to mitigation. These developments demonstrate that increasingly legal scrutiny is taking place in relation to disasters and their impact on human rights.

Although progress has been made, there are many more opportunities to be explored in terms of developing the subject and enhancing accountability in relation to international (human rights) law and disasters. The four contributions in this special column illustrate this point.

\section{Introducing the articles of the special column}

Focusing on sanitation and disaster management, Marie Aronsson-Storrier's contribution sheds light on issues not commonly explored within human rights scholarship. Examining the extent to which states have obligations under IHRL, and taking into account laws and policies on sanitation and disaster management, she argues that states are under a legal obligation to provide sanitation for individuals affected by disasters, prioritizing those in greater need. Arguing in favour of a human rights-based approach to disaster management, she further stresses that such an approach must secure considerable protection of persons while enhancing accountability of State agents in relation to sanitation in disaster management.

The traditionally State centric nature of international law opens for questions of how to account for the complexity and multifaceted nature of disaster management. In their contribution to this column, Marlies Hesselman and Lottie Lane explore the important question of the obligations, duties and responsibilities of non-State actors (NSAs) in disaster governance. Addressing the issue through a human rights lens, they argue that a better understanding of the roles and responsibilities of NSAs is essential in order to strengthen the transparency, coordination, effectiveness, and accountability of disaster management, and that the application of human rights-based approaches to disaster management "by specific actors or sectors" makes important contributions to this process. Moving beyond the state centric nature of IHRL (which indirectly addresses the conduct of NSAs through the obligations for States to regulate private actors' behaviour), 
they conclude that the development of "relevant soft-law instruments and self-regulatory initiatives" has led to NSAs also bearing "direct responsibilities under IHRL", which are highly relevant in the disaster context.

One way to expand our focus is to identify the potential of not only purely human rights standards but also other legal standards and mechanisms which might support the protection of human rights in disasters. Considering the contributions of business to disaster risk, Karen da Costa explores the possibilities for holding multinational corporations (MNCs) accountable for the negative social impact of their activities. Focusing on the extractive sector, and using the 2015 Samarco chemical sludge disaster in Brazil as a case study, da Costa argues that the OECD Guidelines on Multinational Enterprises with their broad and multi-sectoral coverage, are currently the most promising international standard relating to business and accountability for disasters. In particular, their remedy mechanism, whereby complaints can be addressed to specific National Contact Points, constitutes an important complement to other corporate accountability mechanisms, which can prove instrumental for persons and communities that have suffered from MNCs' activities.

Moving on into the urban space, Ronan McDermott et al. focus on the international legal regulation of urban crises, or, in other words, on emergency situations in urban settings. Their coverage encompasses situations of conflict, and of "natural" and technologic disaster. Great emphasis is given to the understanding of urban violence, notably through gangs of youth living in overcrowded and impoverished areas. Focusing on IHL and IHRL, considerations are made in relation to the scenario and intensity of hostilities, as well as the actors involved. The authors further highlight particular features that may increase vulnerability to urban disasters, and the potential of counterbalancing them through States' positive obligations on the right to life, together with the legal protection against forced evictions and relocations. The analysis provides valuable insights on how international law covers such crises, which indeed pose a series of challenges requiring innovative and collaborative ways of addressing them.

\section{Considerations for the future research agenda}

Many issues come into mind when considering the future research agenda on law and disasters. We would argue that there is a need to continue to develop a more coherent corpus of IDL and to consider closely the place, role, and interpretation of various areas of law in disaster management. In addition to this, it would be beneficial to investigate the impact of national laws in the operations of disaster actors and the extent to which existing international instruments and guidelines are implemented into national law, policy and practice. In so doing, it is very important to closely collaborate with the wider disaster management community, so as to learn more about their practice on the ground. Further research topics could touch upon human rights in disasters, an area of burgeoning interest among scholars, but which is still in need of further clarification and development.

As suggested by Kristian Lauta, "research into the interlinkage between human rights and disaster management and its implications on the ground is presently missing, and should form part of the future research agenda for interested scholars" (Lauta, 2016). There is, indeed, a need to further investigate and exchange with disaster practitioners in this area, and much is to be learned on the implications of applying human rights on the ground. For example, how far do or should human rights permeate disaster management activities? Would this politicise disaster actors' work? Would it limit their access to 
communities, causing greater harm than if such a sensitive issue would be simply left out? And would it be possible to conduct effective disaster management while turning a blind eye to human rights issues, such as patterns of discrimination against certain members of society? Bizzarri (2012) argues for the "need to increase sensitivity to diversity and inclusiveness in disaster management" and that "[t]his is currently more of a theoretical commitment than a practice in disaster management." The statement is somewhat controversial, especially because it arises not from a wide empirical study but rather from a rather archetypal legal output, based on the review of the relevant literature and appraisal of the practice of different human rights bodies. If the statement indeed reflects the current situation, we suggest that much more has to be done in order to understand the reasons why only lip service is paid to key issues such as diversity and inclusiveness in disaster management. In order to get tentative answers to these questions, the communication between human rights practitioners (especially lawyers) and disaster practitioners needs to be strengthened.

This column aims to make a contribution in starting this dialogue and exercise, that hopefully will not only benefit various communities of practice, but also, and more importantly, the people on the ground, who are directly affected by disasters and the actions or inactions addressing them.

\section{A final note of thanks}

Finally, we would like to express our sincere gratitude towards many people for providing us with opportunities to further explore and discuss themes relating to this special column. We are in particular grateful to Ilan Kelman for his continuous support and engagement, and the many opportunities he tirelessly offers to early career scholars seeking to contribute to and thrive in the disaster field. We are also very grateful to the editors and reviewers of this journal, and, of, course, our contributing authors. Key events where we discussed aspects of this special column include the 2017 annual conference at the University College London's (UCL) Institute for Reduction of Disaster Risk; the 2016 meeting on law and climate change hosted by UCL Global Governance Institute; and the interdisciplinary DRR and international law symposium hosted by the University of Reading earlier this year. All these events allowed us to sense that there is a real need for and interest from various scholars and practitioners to further explore the relationship between disasters and the law.

This is an exciting period of development for IDL, and this special column covers only a small parcel of the monumental task ahead. Moving forward it is imperative that we find ways to better connect law, scientific findings and humanitarian practice. We are grateful for the opportunity to engage with this journal, and it is our hope that this special column will encourage further critical, constructive and reflective engagement with IDL and the role of law in disaster prevention and management.

\section{References}

African Union Convention for the Protection and Assistance of Internally Displaced Persons in Africa (Kampala Convention) (adopted 23 October 2009, entered into force 06 December 2012). 
ASEAN Agreement on Disaster Management and Emergency Response (adopted 26 July 2005, entered into force 24 December 2009).

Bizzarri, M. (2012), "Protection of Vulnerable Groups in Natural and Man-Made Disasters", in De Guttry, A. et al. (Eds.), International Disaster Response Law, T.M.C. Asser Press, The Hague, pp. 381-414.

Breau, S. C. and Samuel, K. (Eds.) (2016), Research Handbook on Disasters and International Law, Edward Elgar, Cheltenham, UK.

Carmalt, J. and Dale, C. (2012), "Human Rights and Disaster", in Wisner, B., Gaillard, J. C. and Kelman, I. (Eds.), Handbook of Hazards and Disaster Risk Reduction, Routledge, London, pp. 55-64.

Caron, D. D., Kelly, M. J. and Telesetsky, A. (Eds.) (2014), The International Law of Disaster Relief, Cambridge University Press, Cambridge.

Charter of the United Nations (adopted 26 June 1945, entered into force 24 October 1945).

Committee on the Elimination of Discrimination against Women (CEDAW Committee) (2012), "Concluding Observations On The Fifth And Sixth Periodic Reports Of Chile, Adopted By The Committee At Its Fifty-Third Session", CEDAW/C/CHL/CO/5-6, 12 November 2012, Paragraphs 38-39.

Convention concerning the Prevention of Major Industrial Accidents (Prevention of Major Accidents Convention) (adopted 22 June 1993, entered into force 3 January 1997).

Convention on Assistance in the Case of a Nuclear Accident or Radiological Emergency (adopted 26 September 1986, entered into force 26 February 1987).

Convention on the Elimination of Discrimination Against Women (adopted 18 December 1979, entered into force 3 September 1981) (CEDAW).

Convention on the Rights of Persons with Disabilities (adopted 13 December 2006, entered into force 3 May 2008) (CRPD).

Convention on the Rights of the Child (CRC) (adopted 20 November 1989, entered into force 2 September 1990).

Crock, M. (2016), "The protection of vulnerable groups", in Breau, S. C. and Samuel, K. (Eds.), Research Handbook on Disasters and International Law, Edward Elgar, Cheltenham, UK, pp. 383-405.

Cubie, D. (2017) The International Legal Protection of Persons in Humanitarian Crises: Exploring the Acquis Humanitaire, Hart Publishing, London. 
Cubie, D. and Hesselman, M. (2015), "Accountability for the Human Rights Implications of Natural Disasters: A proposal for Systemic International Oversight", Netherlands Quarterly of Human Rights, Vol. 33 No. 1, pp. 9-41.

Da Costa, K. and Pospieszna, P. (2015), "The Relationship between Human Rights and Disaster Risk Reduction Revisited: Bringing the Legal Perspective into the Discussion”, Journal of International Humanitarian Legal Studies, Vol. 6 No. 1, pp. 64-86.

European Convention for the Protection of Human Rights and Fundamental Freedoms (ECHR) (adopted 4 November 1950, entered into force 3 September 1953).

European Court of Human Rights (2008), Budayeva and others v. Russia, Applications nos. 15339/02, 21166/02, 20058/02, 11673/02 and 15343/02.

European Court of Human Rights (2004), Öneryildiz v. Turkey, Application no. 48939/99.

De Guttry, A., Gestri, M. and Venturini, G. (Eds.) (2012), International Disaster Response Law, T.M.C. Asser Press, The Hague.

Hesselman, M. (2013), “Establishing a Full 'Cycle of Protection' for Disaster Victims: Preparedness, Response and Recovery according to Regional and International Human Rights Supervisory Bodies", Tilburg Law Review, Vol. 18, pp. 106-132.

Human Rights Council (2015), "Final Research-based report of the Human Rights Council Advisory Committee on Best Practices and Main Challenges in the Promotion and Protection of Human Rights in Post-disaster and Post-conflict Situations, UN Doc. A.HRC/28/76, available at:

http://reliefweb.int/report/world/final-research-based-report-human-rights-counciladvisory-committee-best-practices-and (accessed 06 September 2017).

Inter-Agency Standing Committee (2011), IASC Operational Guidelines on the Protection of Persons in Situations of Natural Disasters, Brookings-Bern Project on Internal Displacement, January 2011.

IFRC (2000), "World Disasters Report", available at http://www.ifrc.org/Global/Publications/disasters/WDR/9000-WDR2000.pdf (accessed 06 September 2017).

IFRC (2006), "World Disasters Report", available at: http://www.ifrc.org/Global/Publications/disasters/WDR/WDR2006-English-LR.pdf (accessed 06 September 2017).

IFRC (2011), "Introduction to the Guidelines for the domestic facilitation and regulation of international disaster relief and initial recovery assistance", available at: http://www.ifrc.org/PageFiles/41203/1205600-IDRL\%20Guidelines-EN-LR\%20(2).pdf (accessed 06 September 2017). 
IFRC and UNDP (2015), "The Checklist on Law and Disaster Risk Reduction - An annotated outline, October 2015", available at:

http://www.drr-law.org/resources/The-Checklist-on-law-and-DRR-Oct2015-EN-

FINAL.pdf (accessed 06 September 2017).

Inter-American Convention to Facilitate Disaster Assistance (adopted 7 June 1991, entered into force 16 October 1996).

International Convention on Oil Pollution Preparedness, Response and Cooperation (adopted 30 November 1990, entered into force 13 May 1995).

International Covenant on Civil and Political Rights (ICCPR) (adopted 16 December 1966, entered into force 23 May 1976).

International Covenant on Economic, Social and Cultural Rights (ICESCR) (adopted 16 December 1966, entered into force 3 January 1976).

ILC (2016), "ILC Report Containing the Draft Articles on the Protection of Persons in the Event of Disasters and Commentaries", UN Doc. A/71/10, available at:

http://legal.un.org/docs/?path=../ilc/reports/2016/english/chp4.pdf\&lang=EFSRAC

(accessed 06 September 2017).

ILC (2007), Protection of Persons in the Event of Disasters, UN Doc. A/CN.4/590 (Memorandum by the Secretariat).

Kälin, W. and Dale, C. H. (2008), "Disaster Risk Mitigation - Why Human Rights Matter", Forced Migration Review, Vol. 31, pp. 38-39.

Lauta, K.C. (2015), Disaster Law, Routledge, New York, NY.

Lauta, K. C. (2016), "Human Rights and Natural Disasters", in Breau, S. C. and Samuel, K. (Eds.), Research Handbook on Disasters and International Law, Edward Elgar, Cheltenham, UK, pp. 91-110.

Lyster, R. (2016), Climate Justice and Disaster Law, Cambridge University Press, Cambridge, UK.

Macalister-Smith, P. (1981), “The International Relief Union of 1932”, Disasters, Vol 5 No. 2, pp. 147-154.

MacAlister-Smith, P. (1985), International Humanitarian Assistance: Disaster Relief Actions in International Law and Organizations, Springer, Dordrecht.

Organization of African Unity (OAU), African Charter on the Rights and Welfare of the Child (adopted 11 July 1990, entered into force 29 November 1999). 
Peel, J. and Fisher, D. (2016), The Role of International Environmental Law in Disaster Risk Reduction, Brill Nijhoff, Leiden.

Phan, H. L. and Winkler, I. (2016), "Water Security", in Breau, S. C. and Samuel, K. (Eds.), Research handbook on disasters and international law, Edward Elgar, Cheltenham, UK, pp. 295-318.

Rodenhäuser, T. and Giacca, G. (2016), "International Humanitarian Law Framework for Humanitarian Relief during Armed Conflicts and Complex Emergencies.”, in Breau, S. C. and Samuel, K. (Eds.), Research Handbook on Disasters and International Law, Edward Elgar, Cheltenham, UK, pp. 132-152.

Sommario, E. (2012), "Derogation from Human Rights Treaties in Situations of Natural or Man-Made Disaster", in de Guttry, A., Gestri, M. and Venturini, G. (Eds.), International Disaster Response Law, T.M.C. Asser Press, The Hague, pp. 323-352.

Stephens, T. (2016), "Disasters, International Environmental Law and the Anthropocene", in Breau, S. C. and Samuel, K. (Eds.), Research Handbook on Disasters and International Law, Edward Elgar, Cheltenham, UK, pp. 153-176.

Tampere Convention on the Provision of Telecommunication Resources for Disaster Mitigation and Relief Operations (adopted 18 June 1998, entered into force 8 January 2005).

Treaty on the Functioning of the European Union (adopted 13 December 2007, entered into force 1 December 2009).

United Nations (2015), "2015-2030 Sendai Framework for Disaster Risk Reduction, adopted by Third UN World Conference on Disaster Risk Reduction", A/CONF.224/CRP.1.

United Nations General Assembly (2016), "Protection of persons in the event of disasters, Resolution 71/141, UN Doc. A/71/141, 13 December 2016”, available at http://legal.un.org/docs/?symbol=A/RES/71/141

(accessed 06 September 2017).

UN General Assembly, Legal - Sixth Committee (2016), Seventy-first session (3 October11 November), Agenda item 78.

Valencia-Ospina, E. (2008), “The Special Rapporteur's preliminary report on the protection of persons in the event of disasters", UN Doc. A/CN.4/598.

Venturini, G. (2012), "Disasters and Armed Conflicts", in de Guttry, A., Gestri, M. and Venturini, G. (Eds.), International Disaster Response Law, T.M.C. Asser Press, The Hague, pp. 251-266. 
i http://www.ifrc.org/en/what-we-do/disaster-law/about-idrl/

ii https://www.icrc.org/en/war-and-law/treaties-customary-law/geneva-conventions 